\title{
MANIFESTATION OF PROSOCIAL AND ANTISOCIAL BEHAVIOR IN A BASKETBALL MATCH
}

\author{
Saulius Šukys' ${ }^{1}$, Vaida Zakrasienè-Stankevičiūtè ${ }^{1}$, Edas Nickus ${ }^{1}$, Edita Šukienè $\dot{2}^{2}$ \\ Lithuanian Academy of Physical Education', Kaunas, Lithuania \\ Kaunas District Educational Centre ${ }^{2}$, Kaunas, Lithuania
}

\begin{abstract}
Research background and hypothesis. The number of studies examining moral issues in sport has increased but we still lack research about actual behavior of athletes during the match. It was hypothesized that players and coaches' behavior would differ in relation with players' age, course and the final outcome of the match.

Research aim was to explore the manifestation of observed prosocial and antisocial behaviors in a basketball match.

Research methods. Data were collected using observation technique. 40 games were observed in the two age groups: 13-14 and 17-18-year-old players.

Research results. Younger players more often than the older ones demonstrated respect to the referee $(p=0.05)$, but older players showed respect to opponents more often $(\mathrm{p}=0.01)$. In the second half of the game players quarreled with referees more often than at the beginning of the game $(p=0.001)$. When the difference in the final outcome of the game was less, athletes were more often angry with each other $(p=0.001)$ and cursed more often $(p=0.034)$. Coaches working with younger players showed disrespect to them more often $(p=0.02)$.

Discussion and conclusions. Research partly confirmed the hypothesis that younger basketball players more often demonstrated prosocial behavior during the game. Antisocial behaviors of players were more common in the second half of the match and when the difference in the final result was less. Research did not confirm the fact that coaches who worked with older players demonstrated more antisocial behavior and that such behavior was more common when there was less difference in the results of the match.
\end{abstract}

Keywords: basketball players and coaches' behavior assessment, moral behavior in sport, players' age, course of the game, final outcome of the game.

\section{INTRODUCTION}

$\mathrm{S}$ port may be described as a unique moral context encouraging adaptations in participants' moral reasoning (Bredemeier, Shields, 2001). Thus, in the last years the number of studies examining moral issues in sport has increased. The studies deal with judgments about the legitimacy of injurious acts, moral intention (Vallerand et al., 1992), moral judgment, intention, and behavior as indicators of moral functioning (Kavussanu, Ntoumanis, 2003), sports participants and nonparticipants' moral maturity, considering both sport and life moral reasoning (Bredemeier, Shields, 2001), athletes own sportspersonship attitudes, the perceived collective norms of the team, perceptions of the behavior of coaches and spectators (Shields et al., 2007), effects of goal orientations and perceived motivational climate on prosocial and antisocial behavior (Kavussanu, 2006).

Since moral behavior has been typically defined as low frequency of engagement in negative social behaviors, in some studies athletes have been presented with moral dilemmas describing cheating or aggressive behaviors likely to occur during a game, and they were asked to report the frequency of engagement in these behaviors 
during a specified period of time (Kavussanu, Ntoumanis, 2003). This suggests that the studies dealing with athletes' behaviors highlight problems of aggression in sport. Although all these studies expand our understanding of moral behavior in sport, they still have some limitations. One of them refers to overwhelming emphasis on negative social behaviors. But as some scholars suggest, "full representation of social conduct in sport can only be achieved if both positive and negative social acts are examined" (Kavussanu et al., 2006, p. 327). Referring to this consideration we claim that it is important to investigate positive and negative social behavior in the sport context. We will use the terms prosocial and antisocial behaviors to refer to positive and negative acts respectively. Prosocial behavior has been defined as voluntary behavior intended to help or benefit another individual (Eisenberg, Fabes, 1998). Antisocial behavior has been defined as voluntary behavior intended to harm or disadvantage another individual (Eisenberg, Fabes, 1998). Recent research has revealed two factors representing prosocial behavior (prosocial with teammates and opponent) and two factors representing antisocial behavior (antisocial with teammates and opponent) (Kavussanu, Boardley, 2009).

Another limitation of studies examining moral behavior in sport is that moral behavior has been judged exclusively by athletes or coaches' reports rather than actual behavior. Thereby it is important to assess actual athletes' behavior during the game. Research of this kind is topical as all sports competitions are different - they are a complicated dynamic system (Lebed, 2007) the process of which mostly depends on the decisions made by competitors, especially their coaches, in a specific context. Only some studies investigated actual behavior within the sport context. Researchers have observed prosocial and antisocial behaviors of football players of different age and they established that prosocial behavior was less common among players of older age (Kavussanu et al., 2006). It has also been established that losing teams use more aggression during a match (VaezMousavi, Shojaei, 2005 b). A tendency has been observed that awayfrom-home team is more aggressive when they are losing (Jones et al., 2005).

Summing up we can claim that there is still a lack of research about actual behavior during the match as the existing studies are more oriented to the evaluation of aggression. Besides, the findings of the present studies raise more unanswered questions: how athletes' behaviors change in the course of the match and how they differ according to the outcome of the match. Thus, the aim of our research was to explore the manifestation of prosocial and antisocial behaviors of athletes during a basketball match. While analyzing athletes and coaches' behaviors during the match we checked several hypotheses which specified our research aim: (H1) younger basketball players more often demonstrate respect to referees and opponents compared to the older players, (H2) antisocial behaviors of basketball players are more common in the second half of the match, (H3) the smaller the difference in the results at the end of the match, the less respect to the opponents and the referee's decisions is observed, and (H4) coaches who work with older basketball players demonstrate more disrespect to players and referees during a match, and such behavior is more common when there is less difference in the results of the match.

\section{RESEARCH METHODS}

While planning our observations we aimed at defining variables linked to our research object. Thus we carried out pilot observations of two matches where we determined preliminary behavioral patterns which could be attributed to the behavior we were interested in. The list of behavioral patterns was given for the evaluation to two basketball coaches training children. According to their suggestions the preliminary list was corrected, i. e. several actions of athletes which had not been recorded during our pilot observation were added to the list. In this way we distinguished two groups of behavior, i. e. we compiled lists of actions that could be attributed to prosocial and antisocial behavior.

Referring to those changes we made up an observation protocol and then observed two matches. During the observation the coach's actions were given attention. We noticed that it was during the match when the coach demonstrated disrespect to athletes, i. e. the coach shouted at them (e. g. "move on, or you will be running the whole training session"), athletes were incorrectly dubbed (e. g. "asshole", "don't you hear, idiot"). Coaches also showed disrespect to referee's decisions when they started arguing with them, contradicted to them and used obscene words. For this reason we included such actions into our observation protocol. It should be noted that actions of players (bench) 
who were not on the court during the game were not recorded. All in all there were 24 observable variables on the protocol.

The third phase of the research included the analysis of the observation findings aiming at assigning actions to prosocial or antisocial behavioral patterns. The evaluation of prosocial behaviors of basketball players allowed distinguishing the following factors: players' respect to referees (compliance with a foul, compatibility with other referee's decisions), respect to competitors (athletes' apologies after unauthorized actions against an opponent, help when they fall on the ground), and the etiquette of the game (such actions as greeting before and after the game, congratulating a teammate on making a successful shot or passing the ball). It should be noted that while distinguishing the last factor, the etiquette of the game, we referred to the studies by other researchers (Wells et al., 2008), who evaluated such actions as the ones mentioned above as elements of game etiquette. Evaluating the antisocial behavior of athletes we distinguished the following groups: disrespect to referees (noncompliance with a foul, objection to other referee's decisions), anger (being angry with teammates and competitors), conflicts using physical force (pushing teammates or opponents), physical aggression against an opponent, i.e. actions aiming at achieving certain goals but the outcome of which is usually a foul (e. g. the player bars the way, trips the opponent up, etc.). A separate group of antisocial behavior included obscene vocabulary used by athletes. Antisocial behavior of coaches was evaluated as three groups of actions: disrespect to athletes (shouting at them, calling incorrect names), disrespect to referee's decisions (arguments with referees, commenting their decisions) and obscene vocabulary of referees.

In order to measure reliability of the data we estimated inter-observer reliability which was based on the scores of two or more observers who recorded the same information while simultaneously and independently observing the same individual or group behavior (Sattler, Hoge, 2006). Although several procedures are available for measuring inter-observer reliability, we applied percentage agreement calculation. We carried out five control observations when the match was observed by two observers. Then we evaluated the percentage agreement of data recorded by both observers. As the observation took place directly during the match recording behaviors on the protocol, and not watching video-recorded materials, so we did not seek that the agreement was necessarily $100 \%$. Five cases of behavior were agreed upon $100 \%$, two cases - no less than $95 \%$, eight cases - in between $90-95 \%$, and all other cases - up to $90 \%$, but no less than $86 \%$.

Research participants. The chosen research participants were teams of schoolchildren participating in one Lithuanian pupils' basketball tournament. The organizers of the tournament were informed about the research, and their consent to observe the matches was received. It should be noted that the tournament included 81 teams of pupils of different age. We chose the age groups of 13-14 and 17-18 years, the schoolchildren of which played in 43 teams in this tournament. We observed 17 teams in 40 games. Twenty games were observed in the age group of 13-14-year-old children (8 teams), and 20 games - in the group of 17-18-year-old players ( 9 teams). Observation took place in 2008.

Statistical analysis. Analysis was conducted using statistical package SPSS for Windows 13.0. We registered the number of cases of behaviors during the whole research as well as the mean values per one game. Student's $t$ test was applied to verify the hypothesis about the differences in athletes and coaches' behaviors in the aspect of basketball players' age. One-way ANOVA was applied to check the hypotheses about the differences in athletes and coaches' behaviors depending on the final result of the match, the differences in behaviors in the first and the second halves were assessed using Paired - Samples $t$ test. Correlations between the variables of the research were estimated calculating Pearson's correlation coefficient. Statistical significance of differences was set at $\mathrm{p}<0.05$.

\section{RESEARCH RESULTS}

Our research revealed that during a match the mean frequency value of prosocial behaviours demonstrated by basketball players was 60.30 $(\mathrm{SD}=14.79)$ times, and the mean frequency value of antisocial behaviours $-40.20(\mathrm{SD}=15.90)$ times. The assessment of separate behaviours showed that on average basketball players showed respect to a referee $48.58(\mathrm{SD}=12.28)$ times a match, thanked their teammates $11.43(\mathrm{SD}=6.32)$ times and they demonstrated respect to their opponents only 0.3 $(\mathrm{SD}=0.56)$ times. The evaluation of antisocial 
behaviours revealed that during a game the basketball players contradicted to the referee 4.90 $(\mathrm{SD}=4.69)$ times on average, they got angry with other players $0.65(\mathrm{SD}=1.02)$ times, demonstrated physical aggression $23.48(\mathrm{SD}=9.59)$ times and used obscene words $6.53(\mathrm{SD}=5.48)$ times. The coaches shouted at athletes and abused them3.05 $(\mathrm{SD}=3.24)$ times, used obscene words 1.38 $(\mathrm{SD}=2.65$ times and quarrelled with referees 0.63 $(\mathrm{SD}=0.83)$ times.

We did not establish any differences in athletes and coaches' behaviors in the aspect of basketball players' age (Table 1). But it should be noted that a tendency was observed showing that athletes tended to demonstrate unfair behaviors in the second half of the game $(p=0.06)$. Analogous antisocial behavior was more common in those games which ended at a difference less than 10 points $(\mathrm{F}=5.98 ; \mathrm{p}=0.02)$.

The analysis of athletes of different age and their coaches' behaviors during the match revealed more differences (Table 2). Younger players more often than older players demonstrated respect to the referee $(t=2.03 ; p=0.05)$, but older players (though such cases are seldom in general) showed respect to opponents more often $(\mathrm{t}=-2.58$; $\mathrm{p}=0.01$ ). Speaking about antisocial behaviors we should note that older players cursed more often during the game $(\mathrm{t}=-3.74 ; \mathrm{p}=0.001)$. We observed a tendency that more often they disagreed with the referee's decisions. However, coaches working with younger players showed disrespect to them more often $(t=2.37 ; p=0.02)$.

Our findings showed that in the second half of the game basketball players quarreled with referees more often than at the beginning of the game $(t=3.72 ; p=0.001)$. Our observation showed that when the difference in the final outcome of the game was less, athletes were more often angry with each other $(F=43.72 ; p=0.001)$ and cursed more often $(F=4.82 ; p=0.034)$. We found a tendency that coaches were more often angry with players and used obscene words when the game ended with a bigger difference in points.

Significant correlations were found between athletes' contradictions to referees and their anger $(r=0.68 ; p<00.1)$, conflict behavior $(r=0.54$; $\mathrm{p}<0.01)$ and physical aggression $(\mathrm{r}=0.59$, $\mathrm{p}<0.01$ ). By analogy, athletes' anger was linked to physical aggression $(r=0.32 ; p<0.01)$ and the use of obscene vocabulary $(r=0.40 ; p<0.01)$. Negative correlation was established between the use of obscene words by basketball players and their respect to referees $(r=-0.40 ; p<0.01)$. We also found a negative correlation between the players' actions that could be attributed to the etiquette of the game and obscene words used by the coach $(r=-0.37 ; p<0.05)$ as well as players getting into conflicts and coaches' disrespect to the referees $(r=0.42 ; p<0.01)$.

\section{DISCUSSION}

Analyzing the data of basketball players' behaviors in different age groups during the match we established that the first hypothesis of our research was only partly conformed. We hypothesized that younger players would demonstrate respect to referees and opponents more often than their older counterparts. Observation data indicated that younger players more often agreed with the referees' decisions, but they more seldom demonstrated

Table 1. Absolute and mean frequency values of basketball players and coaches' behavior during the game in the aspect of the players' age, the course of the game and final result

\begin{tabular}{|c|c|c|c|c|c|c|}
\hline \multirow{2}{*}{ Research participants } & \multicolumn{6}{|c|}{ Basketball players and coaches' behavior } \\
\cline { 2 - 7 } & \multicolumn{2}{|c|}{$\begin{array}{c}\text { Prosocial behavior of } \\
\text { basketball players }\end{array}$} & $\begin{array}{c}\text { Antisocial behavior of } \\
\text { basketball players }\end{array}$ & \multicolumn{2}{|c|}{$\begin{array}{c}\text { Antisocial behavior of } \\
\text { basketball coaches }\end{array}$} \\
\cline { 2 - 7 } & $\mathrm{N}$ & $\mathrm{M}(\mathrm{SD})$ & $\mathrm{N}$ & $\mathrm{M}(\mathrm{SD})$ & $\mathrm{N}$ & $\mathrm{M}(\mathrm{SD})$ \\
\hline $\begin{array}{c}\text { 13-14-year-old players } \\
\text { 17-18-year-old players }\end{array}$ & 1315 & $62.62(12.59)$ & 790 & $37.62(11.75)$ & 113 & $5.38(3.83)$ \\
& 1097 & $57.74(16.88)$ & 818 & $43.05(19.38)$ & 89 & $4.68(6.04)$ \\
\hline $\begin{array}{c}\text { First half of the game } \\
\text { Second half of the game }\end{array}$ & 1190 & $29.75(7.33)$ & 771 & $19.28(7.85)$ & 107 & $2.68(3.03)$ \\
& 1222 & $30.55(8.66)$ & 837 & $20.93(8.88)$ & 95 & $2.38(2.42)$ \\
\hline $\begin{array}{c}\text { The final result differs in less than } \\
\text { 10 points }\end{array}$ & 853 & $60.92(14.57)$ & 673 & $48.07(12.86)$ & 52 & $3.71(3.95)$ \\
$\begin{array}{c}\text { The final result differs in 10 points } \\
\text { and more }\end{array}$ & 1559 & $59.96(15.18)$ & 935 & $35.96(15.92) *$ & 150 & $5.77(5.38)$ \\
\hline
\end{tabular}

Notes. 1 - Fifteen matches ended with a less difference than 10 points, and 25 matches - 10 points and more. The absolute values show the total number of registered actions in all matches observed. * - statistically significant difference $(\mathrm{p}<0.05)$ comparing expressions of basketball players' antisocial behavior despite their final results. 


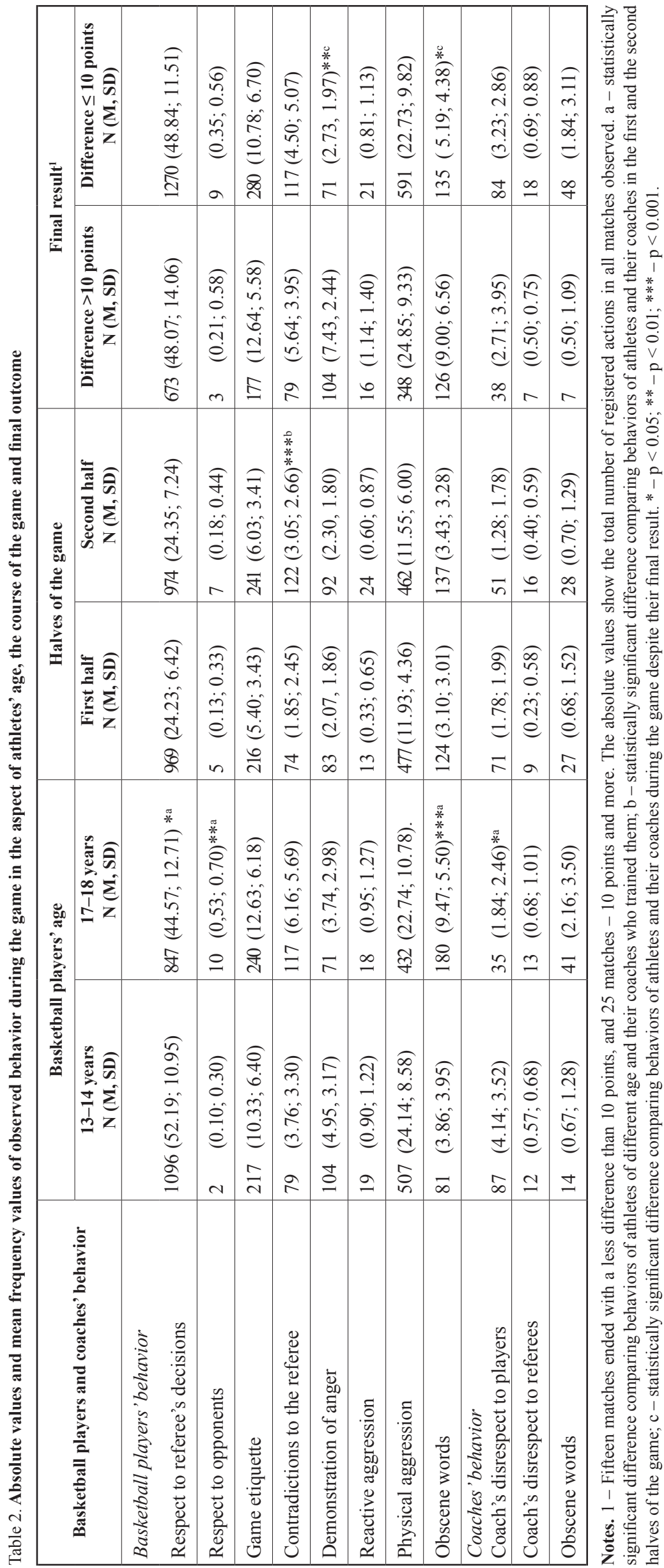


respect to opponents. By analogy, older basketball players more often quarreled with referees and used obscene words in this way showing their dissatisfaction with the course of the game. It should be noted that other researchers who investigated athletes (football players) of similar age established that older than 15-year-old players demonstrated less prosocial behavior than their younger counterparts (Kavussanu et al., 2006). So why older basketball players demonstrated more respect to opponents (though such behavior is rather seldom in general)? This can be explained by the findings of other researchers who observed a different tendency to the ones mentioned above, i.e. prosocial behavior was more common to older basketball players (it should be noted that the subjects were younger compared to the ones in the previously mentioned study) (Arthur-Banning et al., 2009). Researchers explained such facts by the greater number of points earned when the players had more possibilities to express gratitude to their teammates for successful actions. Similarly, we suggest that older basketball players more often demonstrate respect to opponents apologizing for their fouls because at an older age their fouls are ruder compared to the ones of younger players. We also believe that such situations are often discussed in the teams, and older players are more aware of their appropriate behavior under certain conditions. This would also explain the fact that older players more often greet their opponents before and after the game. Besides, older players greet the referees, which is absolutely uncharacteristic of younger players.

Research showed that in the second half of the game basketball players demonstrated more antisocial behavior and this confirmed our second hypothesis. Those results are of no surprise because in the course of the game the tension increases, and this is related to anger and more discussions with referees. Other researchers (Coulomb, Pfister, 1998) have also found that in the second half of the game cases of hostile aggression are more common, and it usually manifests in anger outbursts.

The analysis of basketball players' behavior in the aspect of the final result confirmed our third hypothesis. More antisocial behavior was observed in those matches that ended in less than ten-point difference. This difference was influenced by more common cases of anger, obscene language and contradictions to referees' decisions. These results could be expected as little difference in points testifies persistent sports duel, and each unfavorable decision of the referee or unsuccessful attack as well as certain opponents' actions can stimulate the players to react more sensitively.

The analysis of the coach's behavior revealed only some tendencies which in essence did not confirm our hypothesis that incorrect behavior and quarrels with referees were more common to those coaches who trained older basketball players and such behavior could be more often observed during a tighter game. We established that coaches working with younger players more often called them incorrect names and shouted at them. On the other hand, coaches working with older players more often used obscene vocabulary. We found an opposite tendency to our hypothesis - coaches were angrier with players and referees and more often use obscene words when the game ended in more than 10-point difference. Besides, our research showed that coach's disrespect to referee's decision correlated to athletes' threats to other players. We can draw a conclusion that inappropriate behavior of coaches can encourage inappropriate behavior of their trainees. This supposition has been partly confirmed by other studies which suggest that aggressive verbal communication of coaches determine unfair behaviors of athletes (Hassandra et al., 2007) and that there is a link between the coach's behavior during the game and the level of athletes' aggressiveness (VaezMousavi, Shojaei, 2005 a). While evaluating the influence of the coach on athletes' behavior, it should be noted that athletes' well-being and performance are not so much affected by the coach's manner of speaking, but by nature of the information forwarded (Vargas-Tonsing, 2009). This information can differ greatly. It has been established that during the game the coaches most often give instructions what to do, they praise athletes more seldom, and sometimes they keep silent (Cushion, Jones, 2001). It should be noted that being silent can have a certain meaning.

Though the research data mentioned above suggest that the coach makes influence conveying certain models of behavior to the trainees during the match, some aspects still need consideration. The coach not necessarily has to be polite and friendly to athletes, and the angry tone of voice not necessarily should be evaluated negatively. In the development of athletes' fair behaviors the coach should be more an educator and not a friend (Ciairano et al., 2007), and not only talk about fair behavior, but demonstrate it leading by example. Such behavior would mostly affect athletes' behaviors more than simple talking (Arthur-Banning et al., 2009). Thus 
it is natural that during the game the coaches might lose their temper, be angry with athletes and referees, but they should not exceed a certain threshold and use words that should not be used working with children. The coaches should not use obscene vocabulary either. On the basis of this research we could recommend that while training would-be coaches and counseling already working coaches much attention should be paid to the culture of language and the educational impact of verbal communication on the work with children. Some research data show that up to $70 \%$ of children younger than 13 years old leave sorts activities (Arthur-Banning et al., 2009). There are many reasons for that, but among them is the atmosphere of justifying unfair behavior in the team.

\section{CONCLUSIONS AND PERSPECTIVES}

The present research not only revealed some tendencies of children athletes and coaches' behavior, but also indicated the perspectives for further research. Older basketball players more seldom agree with referees' decisions, but they more often show respect to opponents than younger players. Generally quarrels with referees and anger, obscene words are more common in the second half of the game and in those games which end with a smaller difference in points. More often the coaches demonstrate disrespect to younger players, and they argue with referees more in the second half of the game. Continuing similar research it would be appropriate to evaluate the behavior of the coach of a winning and a losing team. Besides, evaluating the behaviors of coaches in the course of the game, especially their verbal communication, it would be useful to compare male and female coaches. This study was limited to observation of negative behaviors of coaches, but in the future positive behaviors should also be studied. As we investigated only the boys, it is still unclear if the same tendencies are common for the girls playing basketball.

\section{REFERENCES}

Arthur-Banning, S., Wells, M. S., Baker, B. L., Hegreness, R. (2009). Parents behaving badly? The relationship between the sportsmanship behaviors of adults and athletes in youth basketball games. Journal of Sport Behavior, 32 (1), 3-18.

Bredemeier, B. J., Shields, D. L. (2001). Game reasoning and interactional morality. The Journal of Genetic Psychology, 147 (2), 257-275.

Ciairano, S., Gemelli, F., Molinengo, G. et al. (2007). Sport, stress, self-efficacy and aggression towards peers: Unraveling the role of the coach. Cognition. Brain \& Behavior, 11 (1), 175-194.

Coulomb, G., Pfister, R. (1998). Aggressive behaviors in soccer as a function of competition level and time: A field study. Journal of Sport Behavior, 21 (2), 222-232.

Cushion, C. J., Jones, R. L. (2001). A systematic observation of professional top-level youth soccer coaches. Journal of Sport Behavior, 24 (4), 354-376.

Eisenberg, N., Fabes, R. A. (1998). Prosocial development. In N. Eisenberg (Ed.), Handbook of Child Psychology. Vol. 3: Social, Emotional, and Personality Development (pp. 701-778). New York: Wiley.

Hassandra, M., Bekiari, A., Sakellariou, K. (2007). Physical education teachers' verbal aggression and students play fair behavior. Physical Educator, 64 (2), 94-101.

Jones, M., Bray, S., Olivier, S. (2005). Game location and aggression in rugby league. Journal of Sports Sciences, 23 (4), 387-393.
Kavussanu, M., Boardley, I. D. (2009). The prosocial and antisocial behavior in sport scale. Journal of Sport \& Exercise Psychology, 31, 97-117.

Kavussanu, M. (2006). Motivational predictors of prosocial and antisocial behavior in football. Journal of Sports Sciences, 24 (6), 575-588.

Kavussanu, M., Ntoumanis, N. (2003). Participation in sport and moral functioning: Does ego orientation mediate their relationship? Journal of Sport and Exercise Psychology, 25 (4), 501-518.

Kavussanu, M., Seal, A. R., Phillips, R. D. (2006). Observed prosocial and antisocial behaviors in male soccer teams: Age differences across adolescence and the role of motivational variables. Journal of Applied Sport Psychology, 18, 326-344.

Lebed, F. (2007). A dolphin only looks like a fish: Players' behavior analysis is not enough for game understanding in the light of the systems approach - a response to the reply by McGarry and Franks. European Journal of Sport Science, 7 (1), 55-62.

Sattler, J. M., Hoge, R. D. (2006). Assessment of Children. Behavioral, Social, and Clinical Foundations ( $5^{\text {th }}$ ed.). San Diego: Jerome M. Sattler Publisher Inc.

Shields, D. L., LaVoi, N. M., Bredemeier, B. L., Power, F. C. (2007). Predictors of poor sportpersonship in youth sport: personal attitudes and social influence. Journal of Sport and Exercise Psychology, 29 (6), 747-762.

VaezMousavi, S. M., Shojaei, M. (2005 a). Association between Coaches' Behaviors and Players' Aggressive 
and Assertive Actions. International Journal of Applied Sport Sciences, 17 (2), 35-43.

VaezMousavi, S. M., Shojaei, M. (2005 b). Frequencies of aggressive behaviors in win, lose, and tie situations. Iternational Journal of Applied Sport Sciences, 17 (1), 42-50.

Vallerand, R. J., Deshaies, P., Cuerrier, J. P., Pelletier, L. G., Mongeau, C. (1992). Ajzen and Fishbein's theory of reasoned action as applied to moral behavior: A confirmatory analysis. Journal of Personality and Social Psychology, 62 (1), 98-109.

Vargas-Tonsing, T. M. (2009). An exploratory examination of the effects of coaches' pre-game speeches on athletes' perception of self-efficacy and emotion. Journal of Sport Behavior, 32 (1), 92-111.

Wells, M. S., Arthur-Banning, S. G., Paisley, K. P. et al. (2008). Good (youth) sports: Using benefits-based programming to increase sportsmanship. Journal of Park and Recreation Administration, 26 (1), 1-21.

\title{
PROSOCIALAUS IR ANTISOCIALAUS ELGESIO RAIŠKA KREPŠINIO RUNGTYNIŲ METU
}

\author{
Saulius Šukys' ${ }^{1}$ Vaida Zakrasienè-Stankevičiūtė¹, Edas Nickus ${ }^{1}$, Edita Šukienè2 \\ Lietuvos kūno kultūros akademija ${ }^{1}$, Kaunas, Lietuva \\ Kauno rajono edukacinis centras ${ }^{2}$, Kaunas, Lietuva
}

\section{SANTRAUKA}

Tyrimo pagrindimas ir hipoteze. Pastaraisiais metais nemažai tirta aiškinantis vaikų moralinio elgesio sportinejje veikloje ypatumus, tačiau trūksta tyrimų apie realų elgesi per rungtynes. Tyrimo metu stebint žaidejjus ir trenerį keltos hipotezės, kad jų elgesys skirsis priklausomai nuo krepšininkų amžiaus, rungtynių eigos bei galutinio rezultato.

Tikslas - išsiaiškinti prosocialaus ir antisocialaus elgesio raišką krepšinio rungtynių metu.

Metodai. Buvo naudotas stebėjimo metodas. Stebėta 20 rungtynių 13-14 amžiaus grupejje (8 komandos) ir 20 rungtynių 17-18 metų grupejje (9 komandos).

Rezultatai. Vyresni krepšininkai rečiau sutinka su teisèjų sprendimais $(p=0,05)$, tačiau dažniau rodo pagarbą varžovams nei jaunesni $(\mathrm{p}=0,01)$. Antroje rungtynių dalyje krepšininkai dažniau ginčijasi su teisejjais nei rungtynių pradžioje $(p=0,001)$. Pyktis $(p=0,001)$, ypač necenzūriniai žodžiai $(p=0,03)$, būdingesni tose rungtynèse, kurios baigiasi mažesniu skirtumu. Nepagarbą treneris dažniau rodo jaunesniems krepšininkams $(\mathrm{p}=0,02)$.

Aptarimas ir išvados. Tyrimas iš dalies patvirtino keltą hipotezę, kad jauni krepšininkai dažniau rodo pagarbą teisėjams ir varžovams nei vyresni krepšininkai Pasitvirtino kelta hipotezė, kad antroje rungtynių dalyje krepšininkai dažniau elgiasi antisocialiai. Pasitvirtino ir trečioji hipotezè - krepšininkų elgesys skiriasi priklausomai nuo galutinio rungtynių rezultato. Nepasitvirtino hipotezè, kad vyresnius krepšininkus treniruojantys treneriai rodo daugiau nepagarbos žaidejjams bei teisėjams rungtynių metu, ir toks elgesys būdingesnis rungtynėse, kurios baigiasi mažesniu skirtumu. Tęsiant tyrimus tikslinga atskirai ịvertinti laimejjusios ir pralaimejjusios komandos trenerių elgesį. Be to, vertinant trenerių elgesị rungtynių metu, tikslinga palyginti trenerius vyrus ir moteris. Buvo tirti berniukai, todèl lieka neaišku, ar nustatytos tendencijos būdingos ir krepšinį žaidžiančioms mergaitèms.

Raktažodžiai: krepšininkų ir trenerio elgesio vertinimas, moralinis elgesys sportinèje veikloje, žaidèjų amžius, rungtynių eiga, rungtynių galutinis rezultatas.

Gauta 2011 m. lapkričio 5 d.

Received on November 5, 2011

Priimta 2011 m. gruodžio 8 d.

Accepted on December 8, 2011
Corresponding author Saulius Šukys

Lithuanian Academy of Physical Education Sporto str. 6, LT-44221 Kaunas

Lithuania

Tel +37037302657

E-mails.sukys@1kka.lt 